\title{
Combustion and Emission Reduction Characteristics of GTL-Biodiesel Fuel in a Single-Cylinder Diesel Engine
}

\author{
Kibong Choi ${ }^{1}$, Suhan Park ${ }^{2}$,, Hyun Gu Roh ${ }^{1}$ and Chang Sik Lee ${ }^{3, *}$ \\ 1 Department of Mechanical and Automotive Engineering, Induk University, 12 Choansan-ro, \\ Nowon-gu, Seoul 01878, Korea; kbchoi@wabotech.com (K.C.); hgroh@induk.ac.kr (H.G.R.) \\ 2 School of Mechanical Engineering, Chonnam National University, 77 Yongbong-ro, Buk-gu, \\ Gwangju 61186, Korea; suhanpark@jnu.ac.kr \\ 3 School of Mechanical Engineering, Hanyang University, 222 Wangsimni-ro, Seongdong-gu, Seoul 04763, Korea \\ * Correspondence: cslee@hanyang.ac.kr
}

Received: 28 April 2019; Accepted: 5 June 2019; Published: 10 June 2019

\begin{abstract}
The purpose of this paper is to investigate the effects of using gas to liquid (GTL)-biodiesel blends as an alternative fuel on the physical properties as well as the combustion and emission reduction characteristics in a diesel engine. In order to assess the influence of the GTL-biodiesel blending ratio, the biodiesel is blended with GTL fuel, which is a test fuel with various blending ratios. The effects of GTL-biodiesel blends on the fuel properties, heat release, and emission characteristics were studied at various fuel injection timing and blending ratios. The test fuels investigated here were GTL, biodiesel, and biodiesel blended GTL fuels. The biodiesel blending ratio was changed from $0 \%, 20 \%$ and $40 \%$ by a volume fraction. The GTL-biodiesel fuel properties such as the fuel density, viscosity, lower heating value, and cetane number were analyzed in order to compare the effects of different mixing ratios of the biodiesel fuel. Based on the experimental results, certain meaningful results were derived. The increasing rate of the density and kinematic viscosity of the GTL-biodiesel blended fuels at various temperature conditions was increased with the increase in the biodiesel volumetric fraction. The rate of density changes between biodiesel-GTL and GTL are $2.768 \%$ to $10.982 \%$. The combustion pressure of the GTL fuel showed a higher pressure than the biodiesel blended GTL fuels. The biodiesel-GTL fuel resulted in reduced NOx and soot emissions compared to those of the unblended GTL fuel. Based on the experimental results, the ignition delay of the GTL-biodiesel blends increased with the increase of the biodiesel blending ratio because of the low cetane number of biodiesel compared to GTL. As the injection timing is advanced, the NOx emissions were significantly increased, while the effect of the injection timing on the soot emission was small compared to the NOx emissions. In the cases of the HC and CO emissions, the GTL-biodiesel blended fuels resulted in similar low emission trends and, in particular, the HC emissions showed a slight increase at the range of advanced injection timings.
\end{abstract}

Keywords: diesel engine; biodiesel-GTL blending fuel; fuel properties; ignition; exhaust emissions

\section{Introduction}

In the transport sector, the rapid reductions in the use of fossil fuels and exhaust emissions have led to an interest in alternative fuels. Therefore, reducing fuel consumption and exhaust emissions from transportation vehicles is important because of the limited reserves of fossil fuels and the harmful emissions of many vehicles. Gas-to-liquids (GTL) is an alternative synthetic fuel to diesel that converts natural gas into a liquid fuel that is suitable for diesel engines. GTL can be synthesized in several ways, such as the Fischer-Tropsch (FT) synthesis, the methane reforming process, and the hydrocracking process [1,2]. An increasing concern about energy consumption and greenhouse gases have prompted vehicle manufacturers to research and apply alternative fuels and highly efficient engines. 
Significant amounts of nitrogen oxides $\left(\mathrm{NO}_{\mathrm{x}}\right)$ and particulate matter $(\mathrm{PM})$, generated during the combustion process, are obstacles that must be solved for the spread of diesel engines. Therefore, many researchers have investigated optimal technologies for the reduction of harmful emissions. In particular, biodiesel and GTL fuels have various advantages in reducing the emissions from diesel vehicles. GTL fuel is regarded as a colorless, non-toxic, odorless, biodegradable product, and it has several beneficial properties. GTL fuels have a higher cetane number, negligible amount of aromatic compounds, virtually zero sulfur, and no PAH (polycyclic aromatic hydrocarbon) content [3,4]. Hence, they can be considered as an alternative fuel for diesel engines that yields low exhaust emissions without any major modifications [5]. In recent years, several studies on the GTL and GTL-diesel or biodiesel blends in diesel engines have been conducted in attempts to reduce exhaust emissions [5-12]. Some studies of reference [5-12] are summarized in Table 1.

Sajjad et al. [6] reviewed the engine combustion, performance, and emission characteristics of GTL fuels, as well as its blends with diesel and biodiesel, in a diesel engine. That review presented an effective guideline to the design of several blends of alternative fuels, and they analyzed the physiochemical properties and combustion characteristics of GTL and its blends in the diesel engine. Regarding the fuel properties of GTL, it has a lower kinematic viscosity than diesel fuel, and its cetane number (CN) is higher than other diesel engine fuels [13,14]. Soltic et al. [13] investigated the effects of diesel, GTL, and biodiesel fuels on the injection, combustion and pollutant emissions in a compression ignition (CI) engine operated at near full load and equipped with a combined exhaust gas after-treatment system. In their study, the oxygenated fuels (rapeseed methyl ester (RME), neat soybean and rapeseed oil) increased the brake thermal efficiency and $\mathrm{NO}_{\mathrm{x}}$ emissions. In particular, the raw emissions from the engine contained substantially more soot emission for conventional diesel and GTL than for neat soybean and rapeseed oil. In another study, Hassaneen et al. [14] investigated the fuel economy and emission characteristics of GLT, RME and diesel fuels for a multi-cylinder diesel engine. They found that the unburned hydrocarbon (HC) emissions from RME biodiesel were far lower than those of GTL and diesel fuel. The $\mathrm{NO}_{\mathrm{x}}$ emission of GTL fuel was very slightly lower than that of conventional diesel, and biodiesel showed a noticeably higher value than diesel fuel for all tested engine loads. The main reason for the elevated $\mathrm{NO}_{\mathrm{x}}$ emission for biodiesel is the chemical composition, which contains the oxygen content in a fuel molecule [14]. In addition, the PM emissions emitted from GTL and diesel fuels were higher than the EURO-V requirements, but those of biodiesel were almost $60 \%$ lower than those of GTL and diesel [14]. For the similar combustion phasing, $\mathrm{HC}$ and $\mathrm{CO}$ emissions were reduced with GTL fuel, and the smoke opacity was lower than that of conventional diesel [7]. In this work, we try to investigate the effect of a higher CN of GTL and oxygenated content in a biodiesel molecule of biodiesel by applying the GTL-biodiesel blends. The aforementioned investigations of alternative fuels for diesel engines reported that the fuel consumption of biodiesel is considerably higher, and that the CO and PM emissions were reduced when compared to GTL and diesel. Regarding GTL fuel, $\mathrm{NO}_{x}$ and HC emissions were reduced compared to conventional diesel fuel [7,11-14]. They found that the $\mathrm{NO}_{\mathrm{x}}$ and $\mathrm{HC}$ emissions were lower than those of conventional diesel fuel because of the low combustion temperature caused by the shorter ignition delay for GTL in comparison to diesel fuel [15]. Furthermore, the GTL properties of a lower density and aromatic content play an important role in reducing $\mathrm{NO}_{x}$ emissions [15-19]. Regarding the particle size distribution of GTL, Li et al. [20] found reductions in the total exhaust particle number and volume concentrations for GTL when compared to conventional diesel. In their research, the total exhaust particle number and volume concentrations were reduced by $18-92 \%$ and $21-59 \%$, respectively, under the same operation conditions. Regarding multi-cylinder diesel engines, the variations in the total particle number emissions for GTL show a greater reduction of the total particle number from the engine under all load conditions $[14,15,20]$. Most of the above references in this section dealt with the combustion study of GTL and its blends. However, more study is required in relation to the transient performance and emission, combustion effects of various alternative fuels, and physical properties of GTL and GTL-biodiesel blends in terms of neat fuel or alternative fuels involving GTL. 
Table 1. Summary of recent research papers.

\begin{tabular}{|c|c|c|c|}
\hline $\begin{array}{l}\text { [Ref.\#] First } \\
\text { Author (Year) }\end{array}$ & Engine Type (Disp.) & Test Fuels & Featured Results \\
\hline $\begin{array}{l}\text { [5] Sajjad et al. } \\
\text { (2015) }\end{array}$ & $\begin{array}{l}\text { 4-cylinder Water-cooled Turbocharged } \\
\text { Diesel engine }(2477 \mathrm{cc})\end{array}$ & $\begin{array}{l}\text { Diesel } \\
\text { CI20 (20\% CIBD + 80\% Diesel }) \\
\text { G20 (20\% GTL + 80\% Diesel) } \\
\text { DCIG20 (30\% CIBD + } 20 \% \text { GTL } \\
\quad+50 \text { Diesel })\end{array}$ & $\begin{array}{l}\text { - } \quad \text { All blended fuels have a higher cetane number and flash point than diesel. } \\
\text { - } \text { rate were high in CI20 and DCIG20 and low in G20. } \\
\text { - G20 has a higher BTE, and DCIG20 has a lower BTE than diesel. } \\
\text { - } \quad \text { All blended fuels showed low CO, HC, and smoke emission. } \\
\text { - In NOx, only G20 was decreased, other blended fuels were increased over diesel. }\end{array}$ \\
\hline $\begin{array}{l}\text { [7] Octavio et al. } \\
\text { (2013) }\end{array}$ & $\begin{array}{l}\text { 4-cylinder Intercooled Turbocharged } \\
\text { Light-duty diesel engine ( } 2000 \mathrm{cc})\end{array}$ & $\begin{array}{l}\text { Diesel } \\
\text { GTL } \\
\text { Biodiesel }\end{array}$ & $\begin{array}{l}\text { - Comparison of the characteristics of two fuels at cold and hot start on EGR-applied engines. } \\
\text { - Increase in the HC, CO, and particle number during cold start regardless of test fuels. } \\
\text { In the hot start engine, the concentration of particles was low in the order of diesel, } \\
\text { biodiesel, and GTL. } \\
\text { - High NOx emissions of GTL and biodiesel during the cold start. }\end{array}$ \\
\hline $\begin{array}{l}\text { [9] Jiakun et al. } \\
\text { (2014) }\end{array}$ & $\begin{array}{l}\text { 4-cylinder Intercooled Turbocharged } \\
\text { Light-duty diesel engine (3168 cc) }\end{array}$ & Diesel GTL 10, 20, 30, 60, 100 [Vol \%] & $\begin{array}{l}\text { - In both low and high load conditions, the amount of fuel burned in the premixed } \\
\text { combustion phase is reduced when compared to diesel fuel. } \\
\text { - As the GTL volume fraction increased, the maximum heat generation rate of the premixed } \\
\text { combustion phase decreased. } \\
\text { - An improved combustion noise by reducing the pressure increase as the GTL volume ratio } \\
\text { increased under high load conditions. } \\
\text { - Improve particle emissions when using GTL blended fuels in transient driving conditions. }\end{array}$ \\
\hline $\begin{array}{l}\text { [10] Samir et al. } \\
\text { (2017) }\end{array}$ & $\begin{array}{l}\text { 4-cylinder VGT Intercooled, Light-duty } \\
\text { diesel engine (1994 cc) }\end{array}$ & $\begin{array}{c}\text { Diesel } \\
\text { Summer GTL } \\
\text { Winter GTL }\end{array}$ & $\begin{array}{l}\text { - The combustion efficiency of GTL blended fuels is better due to the higher cetane number. } \\
\text { - An improved fuel consumption during the cold start compared to diesel fuel. }\end{array}$ \\
\hline $\begin{array}{l}\text { [11] Wang et al. } \\
\text { (2009) }\end{array}$ & $\begin{array}{l}\text { 6-cylinder Intercooled Turbocharged diesel } \\
\text { engine }(5900 \mathrm{cc})\end{array}$ & Diesel & $\begin{array}{l}\text { - Compared with diesel, GTL showed a slight lower maximum torque and maximum power } \\
\text { (approximately } 2 \% \text { ). } \\
\text { - Increases the volume of fuel consumption, but does not change the mass and decreases the } \\
\text { thermal efficiency slightly. } \\
\text { - Decreases NOx as } 13 \% \text { (Max), CO as } 55 \% \text { (Max), and THC as } 55 \% \text { (Max) }\end{array}$ \\
\hline $\begin{array}{l}\text { [12] Magin et al. } \\
\text { (2010) }\end{array}$ & $\begin{array}{l}\text { 4-cylinder Intercooled Turbocharged diesel } \\
\text { engine }(2200 \mathrm{cc})\end{array}$ & $\begin{array}{c}\text { Diesel } \\
\text { Biodiesel } \\
\text { GTL } \\
\text { G30B70 } \\
(30 \mathrm{GTL}+70 \% \text { Biodiesel })\end{array}$ & $\begin{array}{l}\text { - Use of biodiesel and GTL in the low and mid-load conditions of the European Vehicle } \\
\text { Certification cycle reduces the concentration of HC, smoke, particulate matter and total } \\
\text { number of particles. } \\
\text { - PM reduction by GTL is larger than that by biodiesel. } \\
\text { - Possible future emission regulation to be met depending on the appropriate blending of } \\
\text { biodiesel and GTL, after-treatment devices, and injection strategies. }\end{array}$ \\
\hline
\end{tabular}


In order to assess the applicability of GTL and its blends to compression ignition engines, the effects of GTL and GTL-biodiesel blends on the combustion and emission reduction characteristics were investigated in a single-cylinder diesel engine. In addition, the physical and chemical properties of test fuels, specifically the density, kinematic viscosity, cetane number, and heating value, were measured and analyzed with respect to the blending ratio of GTL and biodiesel.

\section{Experimental Section and Procedure}

\subsection{Test Engine with Various Measurement System}

Figure 1 shows a schematic diagram of the GTL and biodiesel-blended GTL-fueled diesel engine, as well as the arrangement of the test apparatus. In this experiment, a single-cylinder diesel engine with a $0.373 \mathrm{~L}$ piston displacement and a 17.8 compression ratio was used as the test engine. The bore and stroke of the engine cylinder were $75 \mathrm{~mm}$ and $84.5 \mathrm{~mm}$, respectively. The value mechanism was composed of the double overhead cam type (DOHC) with two exhaust valves and two intake valves. The engine used in this investigation had a re-entrant type piston head. The engine speed and power were controlled and measured using an eddy current (EC) dynamometer (AG150, Froude) with $150 \mathrm{~kW}$ at $8000 \mathrm{rpm}$. The maximum torque of the dynamometer is $500 \mathrm{Nm}$. The torque measurement accuracy and speed measurement accuracy of the dynamometer are $\pm 0.25 \%$ and $\pm 1 \mathrm{rpm}$, respectively. The detailed specifications of the test engine system are presented in Table 2. The exhaust emissions from the engine were measured and analyzed using an exhaust emission analyzer for $\mathrm{HC}, \mathrm{CO}$, and $\mathrm{NO}_{\mathrm{x}}$ (Horiba, MEXA-554JKNOx). In addition, the soot emission was measured by a smoke meter (AVL, 415S) with a nondispersive infrared rays method for sampling the raw gas from the tail-pipe. The soot concentration was presented as the filter smoke number (FSN) of a filter type smoke meter. The $\mathrm{NO}_{\mathrm{x}}$ concentration was measured using a chemical luminescence detector (CLD). Table 3 shows the main specifications of the exhaust gas analyzer.

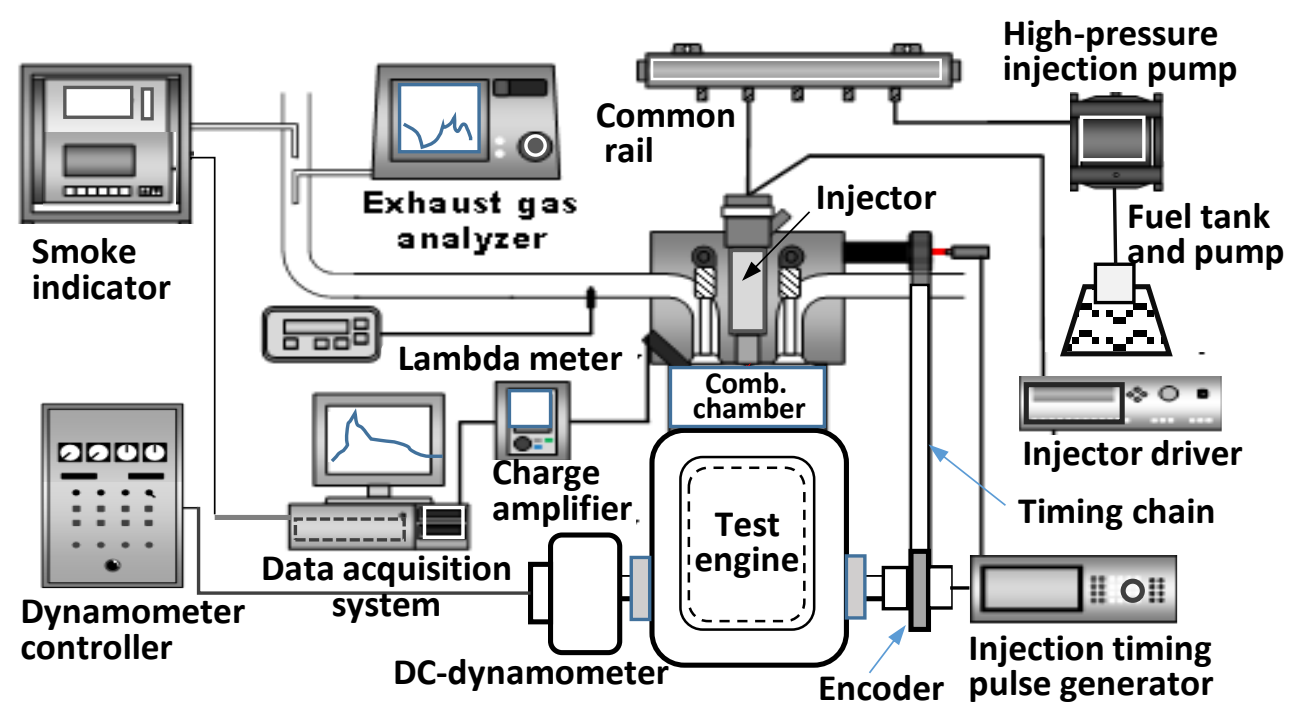

Figure 1. Schematic diagram of the experimental set-up. 
Table 2. Specifications of the test engine and injector.

\begin{tabular}{|c|c|c|}
\hline \multicolumn{2}{|c|}{ Item } & Specification \\
\hline & Direct injection diesel engine \\
\hline \multicolumn{2}{|c|}{ Number of cylinders } & 1 \\
\hline \multicolumn{2}{|c|}{ Bore $\times$ stroke } & $75 \mathrm{~mm} \times 84.5 \mathrm{~mm}$ \\
\hline \multicolumn{2}{|c|}{ Displacement volume } & $0.3733 \mathrm{~L}$ \\
\hline \multicolumn{2}{|c|}{ Compression ratio } & 17.3 \\
\hline \multicolumn{2}{|c|}{ Valve mechanism } & DOHC 4 valves \\
\hline \multicolumn{2}{|c|}{ Fuel injection system } & Bosch common rail \\
\hline \multirow{3}{*}{ Injector } & Hole diameter & $0.131 \mathrm{~mm}$ \\
\hline & Number of holes & 8 \\
\hline & Spray angle & $153^{\circ}$ \\
\hline \multirow{4}{*}{ Valve timing } & \multirow{2}{*}{ Intake valve } & Open BTDC $8^{\circ}$ \\
\hline & & Close ABDC $52^{\circ}$ \\
\hline & \multirow{2}{*}{ Exhaust valve } & Open BBDC $8^{\circ}$ \\
\hline & & Close ATDC $38^{\circ}$ \\
\hline
\end{tabular}

Table 3. Specifications of the emission analyzers.

\begin{tabular}{|c|c|}
\hline \multicolumn{2}{|c|}{ Exhaust Emission Analyzer for $\mathrm{NO}_{\mathrm{x}}, \mathrm{HC}, \mathrm{CO}$} \\
\hline Item & Specification \\
\hline Model & MEXA-554JK \\
\hline Principle of measurement & $\begin{array}{l}\mathrm{CO}, \mathrm{HC} \text { : Non-dispersive infrared rays } \\
\mathrm{NO}_{\mathrm{x}} \text { : Chemical method (ECS sensor) }\end{array}$ \\
\hline Range & $\begin{array}{c}\text { HC: } 0 \sim 10,000 \text { ppm vol. } \\
\text { CO: } 0 \sim 10 \% \text { vol. } \\
\text { NO }_{x}: 0 \sim 4000 \text { ppm }\end{array}$ \\
\hline Repeatability & $\begin{array}{c}\text { HC: } \pm 12 \text { ppm vol. } \\
\text { CO: } \pm 0.06 \% \text { vol. } \\
\mathrm{NO}_{\mathrm{x}}: \text { Less than } \pm 1.0 \%\end{array}$ \\
\hline Response & $\begin{array}{l}\mathrm{HC} \text { and CO: } 90 \% \text { response within } 10 \mathrm{~s} \\
\qquad \mathrm{NO}_{\mathrm{x}}: \text { within } 30 \mathrm{~s}\end{array}$ \\
\hline \multicolumn{2}{|c|}{ Exhaust Emission Analyzer for Soot } \\
\hline Item & Specification \\
\hline Model & AVL-415S \\
\hline Principle of measurement & Filter paper method \\
\hline Measuring range & $0 \sim 10 \operatorname{FSN}\left(0 \sim 32,000 \mathrm{mg} / \mathrm{m}^{3}\right)$ \\
\hline Repeatability & $0.005 \mathrm{FSN}+3 \%$ \\
\hline Response & $0.001 \mathrm{FSN} / 0.01 \mathrm{mg} / \mathrm{m}^{3}$ \\
\hline
\end{tabular}

\subsection{Test Fuels and Experimental Procedure}

In this work, GTL-biodiesel-blended fuels and undiluted GTL fuel were used for the engine combustion and emission analysis. In order to compare the effects of GTL and GTL-biodiesel blends, the GTL-biodiesel blending ratio was adjusted by changing the biodiesel volumetric ratios in the blends. The blending ratio is expressed as the volumetric fraction of GTL in the GTL-biodiesel blends; for example, the blends G80B20 and G60B40 fuels are mixed with $80 \%$ and $60 \%$ of GTL in the blended fuels, respectively. In this blending process, the biodiesel fuel mixed with GTL was derived from soybean oil. The properties of the test fuels of the diesel, GTL, and biodiesel are listed in Table 4.

The engine experiment was conducted at an engine speed of $1200 \mathrm{rpm}$ and an injection pressure of $160 \mathrm{MPa}$. In addition, the fuel injection system consisted of a solenoid type injector with an eight-hole nozzle controlled by an injector driver (TEMS, TDA-3300H, Korea). The ambient pressures and injection 
quantity were $0.1 \mathrm{MPa}$ and $10 \mathrm{mg} /$ stroke, respectively. An injector driver synchronized with a crank angle sensor was used to control the fuel injection quantity and injection timing.

Table 4. Properties of the test fuels.

\begin{tabular}{ccccc}
\hline Test Items & Test Method & Diesel & GTL & Biodiesel \\
\hline Density $\left(\mathrm{kg} / \mathrm{m}^{3}\right.$ at $\left.15^{\circ} \mathrm{C}\right)$ & EN 12185 & 826.2 & 778.4 & 882.2 \\
Viscosity $\left(\mathrm{mm}^{2} / \mathrm{s}\right.$, at $\left.40{ }^{\circ} \mathrm{C}\right)$ & EN ISO 3104 & 2.359 & 2.704 & 4.2 \\
Total sulfur $(\mathrm{mg} / \mathrm{kg})$ & EN ISO 20846 & 7.4 & 7.4 & 1 \\
Cetane index & EN ISO 4264 & 53.2 & 85.5 & 54.7 \\
Flash point $\left({ }^{\circ} \mathrm{C}\right)$ & EN ISO 2719 & 61.0 & 85.0 & 180 \\
Pour point $\left({ }^{\circ} \mathrm{C}\right)$ & ASTM D 97 & -39 & -24 & -5 \\
Cloud point $\left({ }^{\circ} \mathrm{C}\right)$ & ASTM D 2500 & -10 & -19 & 4 \\
Ash content $(\mathrm{wt} \%)$ & EN ISO 6245 & 0.001 & 0.001 & 0.002 \\
Polycyclic aromatic hydrocarbons (wt $\%)$ & EN 12916 & 1.6 & 0 & - \\
Lower heating value, MJ $/ \mathrm{kg}$ & ASTM D 240 & 43.038 & 43.561 & 31.926 \\
CFPP $\left({ }^{\circ} \mathrm{C}\right){ }^{*}$ & ASTM D 6371 & -27 & -20 & 0 \\
\hline
\end{tabular}

* CFPP: cold filter plugging point.

The combustion pressure in the engine cylinder was measured using a piezoelectric pressure sensor (Kistler, 6052A80, Switzerland) connected to a charge amplifier (Kistler, 5011B). During the pressure measuring process, the charge amplifier converted the electric charge produced by the pressure transducer into a proportional voltage signal. The pressure data were obtained from a data acquisition system (National Instruments, PCI-MIO-16E-1, USA) with a sampling interval of a $0.1^{\circ}$ crank angle to determine the injection timing and combustion phase duration for 300 cycles. In assessing the combustion performance, the measured pressure data for the crank angle (CA) were averaged in order to observe the cycle-to-cycle variations. The concentrations of exhaust emissions from the engine were measured, and their concentration of GTL-biodiesel blends were compared to those of the neat GTL fuel.

\section{Results and Discussions}

\subsection{Fuel Properties of GTL-Biodiesel Blends}

Fuel properties generally play important roles in combustion performance and emission reduction. Before the application of GTL and GTL-biodiesel blended fuels to diesel engines, the fuel properties, such as the density, kinematic viscosity, cetane number, and lower heating value (LHV), were measured and analyzed.

Figure 2 shows the kinematic viscosity and density of GTL-biodiesel blends according to the GTL blending ratio. As shown in the figure, the fuel density decreased with an increasing GTL blending ratio. The fuel density is a very important factor for the momentum of the fuel droplet and influences the spray behavior, including the spray tip penetration and spatial distribution of droplets in the combustion chamber. The viscosity of GTL-biodiesel blends also decreased with increasing GTL blending ratios. Based on these results, one could consider that the higher fraction of GTL fuel in the blends influences the injection characteristics, such as the spray momentum and droplet size. The details on the density and kinematic viscosity of the GTL-biodiesel-blended fuels are shown in Figures 3 and 4.

As illustrated in Table 3, the density of the GTL fuel is lower than the densities of the diesel and biodiesel fuel, and the viscosity is lower than that of the biodiesel fuel. In this work, the rate of the density changes of the GTL-biodiesel blends at various fuel temperatures are calculated using the empirical formula investigated by Park et al. [21]. The empirical formula of the fuel density according to the temperature change can be determined using the following equation [21]:

$$
\rho_{\text {Blend }}=A-B T
$$


where $\rho_{\text {Blend }}$ is the density of the blend $\left(\mathrm{kg} / \mathrm{m}^{3}\right), T$ is the fuel temperature $\left({ }^{\circ} \mathrm{C}\right)$, and $A$ and $B$ are the experimental constants. In this case, the rate of the density change is calculated from the ratio of the density difference between the density at some arbitrary temperature and the density at $20^{\circ} \mathrm{C}$, as follows:

$$
r_{\text {Density }}=\frac{\rho_{\text {Blend }}-\rho_{G T L, 20}{ }^{\circ} \mathrm{C}}{\rho_{G T L, 20}{ }^{\circ} \mathrm{C}} \times 100 \%
$$

where $r_{\text {Density }}$ is the rate of the density change $(\%)$, and $\rho_{G T L}, 20^{\circ} \mathrm{C}$ is the GTL density at $20^{\circ} \mathrm{C}$ and $1 \mathrm{~atm}$.

As shown in Table 1, the densities of the GTL and biodiesel are $778.4 \mathrm{~kg} / \mathrm{m}^{3}$ and $882.2 \mathrm{~kg} / \mathrm{m}^{3}$ at $15^{\circ} \mathrm{C}$, respectively. For the pure fuels, the difference in the density between the biodiesel and GTL at $15^{\circ} \mathrm{C}$ is $103.8 \mathrm{~kg} / \mathrm{m}^{3}$, which is $13.3 \%$ higher than that of the GTL fuel. In order to compare the rate of the density change, we calculated the rate of the density change using Equation (2) and showed the result in Figure 3. The rate of the density changes of the biodiesel blended GTL fuel significantly decreased as the GTL blending ratio increased. For example, the rate of the density changes between G80B20 and GTL at $20^{\circ} \mathrm{C}$ is $2.768 \%$, while those of G60B40, G40B60 and G20B80 are 5.665\%, $8.185 \%$, and $10.982 \%$, respectively. Moreover, the rate of the fuel property change according to the temperature change is calculated by the percentage of the property difference between the GTL-biodiesel blend and GTL. As the GTL blending fraction increases, the rate of the density changes of the GTL-biodiesel blends was significantly reduced with an increasing fuel temperature.

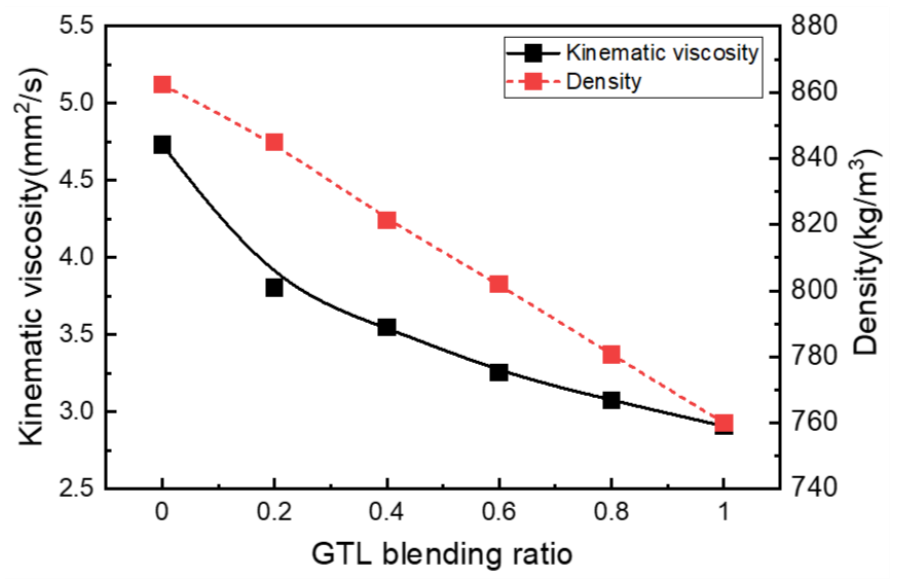

Figure 2. The kinematic viscosity and density of the GTL-biodiesel fuel due to the GTL fraction.

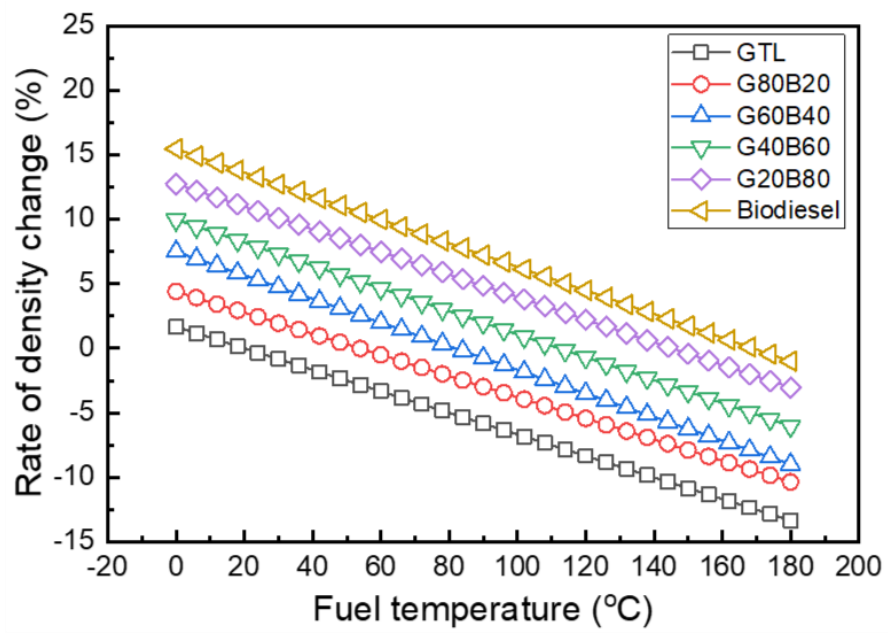

Figure 3. The increasing density rate of the GTL- biodiesel blends. 
Based on the changes in the kinematic viscosity caused by the temperature variation, the empirical equation of the kinematic viscosity and its constant of the GTL-biodiesel blends are given by Park et al. [21]. In this investigation, the rate of the kinematic viscosity of blends is calculated by using the viscosity obtained from Equation (3):

$$
v_{\text {blend }}=\alpha^{\prime}+\beta^{\prime} \exp \left(-\frac{T-\delta^{\prime}}{\gamma^{\prime}}\right)
$$

In this equation, $v_{\text {blend }}$ is the blend viscosity, and $\alpha^{\prime}, \beta^{\prime}$ and $\delta^{\prime}$ are the constants determined by Park et al. [21]. Figure 4 shows the rate of the kinematic viscosity change $\left(r_{\text {viscosity }}\right)$ of the biodiesel blended GTL fuels at various temperature conditions. In this figure, the rate of the viscosity change is calculated by using the same type of Equation (2) as that used for the GTL-biodiesel viscosity. The rate of the viscosity change showed a decreasing trend with increasing GTL blending ratios. In general, the kinematic viscosity of the neat biodiesel is higher than that of the GTL fuel because of the higher density and increased molecules per unit volume compared to the GTL fuel. As presented in Table 3, comparing the fuel viscosities of the three fuels yields that the viscosity of the biodiesel is the highest among the test fuels. With an increase in the test fuel temperature, the rate of the viscosity changes gradually decreased in accordance with the increase in the biodiesel volume fraction.

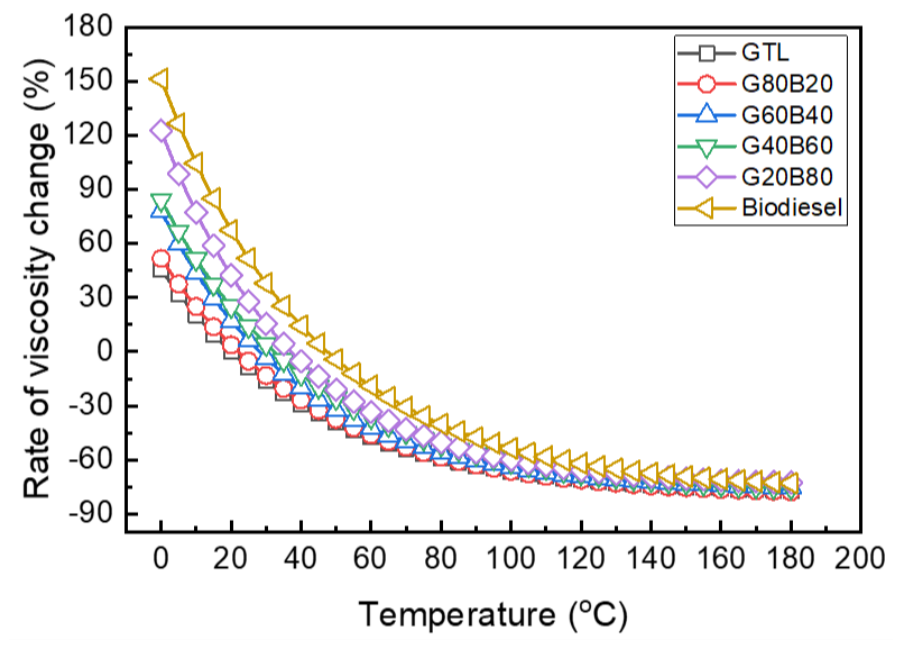

Figure 4. Increasing rate of kinematic viscosity of the GTL-biodiesel blends.

The cetane number (CN) and lower heating value (LHV) of the GTL-biodiesel blends according to the GTL blending ratio are shown in Figure 5. As shown in this figure, as the GTL fraction increased, the $\mathrm{CN}$ at the blending ratio 0 was 54.5 , and the $\mathrm{CN}$ was 85.5 at the GTL blending ratio 1.0, while the LHV of the blends were $31.926 \mathrm{MJ} / \mathrm{kg}$ and $43.561 \mathrm{MJ} / \mathrm{kg}$ at the GTL blending ratios 0 and 1.0, respectively. The LHV of the GTL-biodiesel blends were increased as the GTL content was added. The increase in GTL with a relatively higher LHV in the blend resulted in an increased total heating value. As shown in the increasing trend of the $\mathrm{CN}$, the increase in the GTL fraction led to an increase in the $\mathrm{CN}$ of the GTL-biodiesel blend because the GTL fuel has a higher CN than the biodiesel fuel.

Consequently, the following conclusions can be drawn from the results of an analysis of the properties of the GTL-biodiesel blended fuels as shown above. The disadvantages that can occur when using biodiesel fuel alone (bad atomization performance due to a high kinematic viscosity, low LHV, etc.) can be solved with GTL blending. When the GTL is blended with the biodiesel fuel, it can improve the LHV of the biodiesel while also lowering the viscosity, which can be expected to improve fuel atomization. Blending GTL also increases the cetane number compared to biodiesel, so it can be expected to improve the combustion quality and performance. 


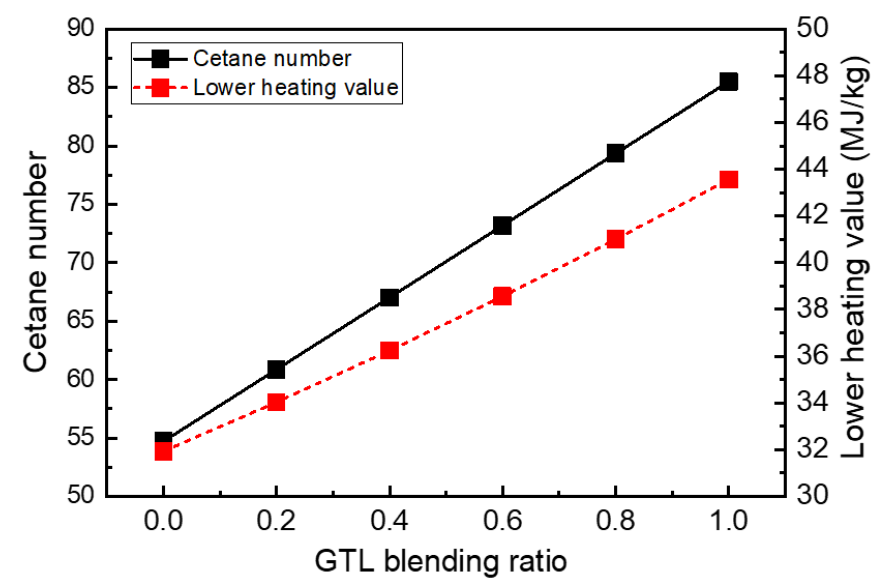

Figure 5. CN and LHV at various GTL blending ratios.

\subsection{Combustion and Emission Characteristics}

Figure 6 shows the combustion pressure and rate of heat release (ROHR) characteristics of the GTL-biodiesel blended fuels at an injection pressure of $160 \mathrm{MPa}$ and injection timing of $3^{\circ}$ BTDC. The combustion pressure histories of the GTL fuel were shown to be higher than those of the biodiesel blended GTL fuels. As indicated in the pressure-crank angles curve (Figure 6a), the combustion pressures in the cylinder were increased with the increasing GTL volumetric fraction because the lower distillation characteristics of GTL improve the spray characteristics and atomization performance. Comparing the distillation properties of the GTL and diesel fuel yields that the $90 \%$ distillation point (T90) is about 6.3\% lower that of the diesel fuel [5]. Therefore, the lower T90 assists the evaporation and combustion characteristics of the GTL fuel. Regarding the fuel properties, the higher CN and low T90 play an important role in the heat generation and rate of heat release, as shown in the figure. In addition, Figure 6 shows the earlier ignition in the GTL. This can be attributed to the higher CN of the GTL (the blending of the biodiesel leads to a decreased CN in the blended fuels). A detailed discussion of the ignition delays is presented in Figure 7.

Increasing the GTL blending ratios leads to an earlier ignition and lower peak rate of the heat release, as illustrated in Figure $6 \mathrm{~b}$. As mentioned previously, the combustion pressure, fuel properties (such as the higher $\mathrm{CN}$ and lower T90) and improved evaporation characteristics of the GTL and GTL-biodiesel blends leads to improve ignition characteristics. As compared to the unblended GTL fuel, the GTL-blended fuels showed an earlier ignition and lower peak ROHR. These are attributed to the higher $\mathrm{CN}$ and lower LHV of the GTL.

Figure 7 shows the ignition delay of the GTL-biodiesel blends with varying amounts of the biodiesel content in the blends. In this study, the ignition delay is defined as the period between the ignition timing (CA10) and injection timing. CA10 was calculated from the amount of heat release, and it represents the point where the amount of heat corresponds to $10 \%$ of the total heat generation. As shown in the figure, the decreased GTL fraction in the GTL-blended biodiesel fuels resulted in the extension of the ignition delay. The ignition delay, in particular the chemical ignition delay, is mainly affected by the activation energy and fuel characteristics. Hence, the ignition delay increases with a decreased proportion of high-cetane fuel (GTL). Comparing the CN of the biodiesel and GTL fuel yields that the CN of the GTL is 85.5 while that of the biodiesel is 54.7, which is 20.8 lower. In addition, the ignition delay is inversely proportional to the temperature according to the equation for the ignition delay $\left(\tau_{i d}=A P^{-n} \exp \left(E_{a} / R_{u} \times T\right)\right)$. Hence, the retardation of the injection timing induced increased ignition delays in all test fuels (GTL, G80B20 and G60B40). 


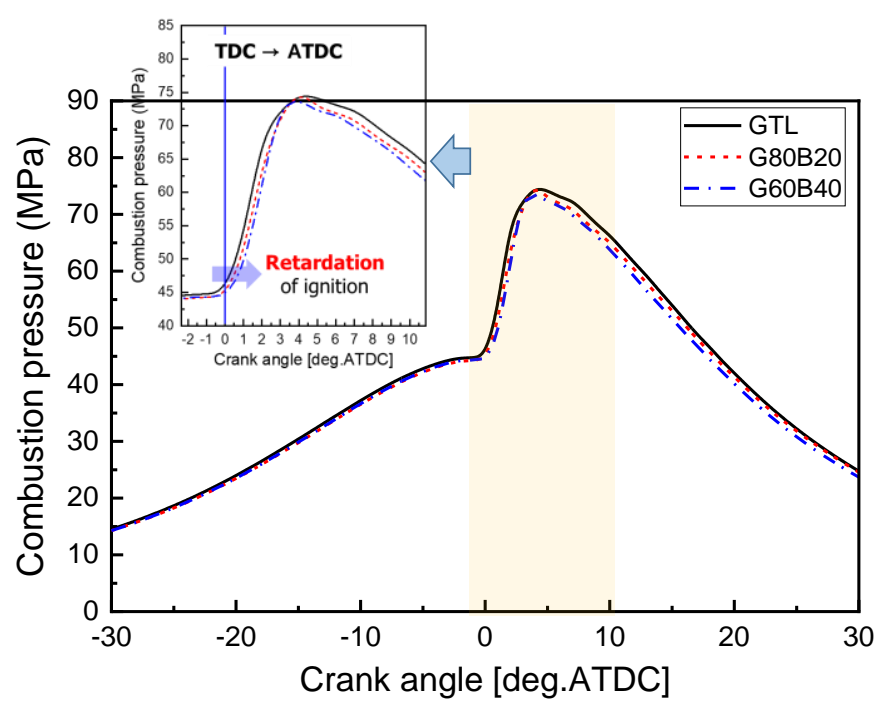

(a)

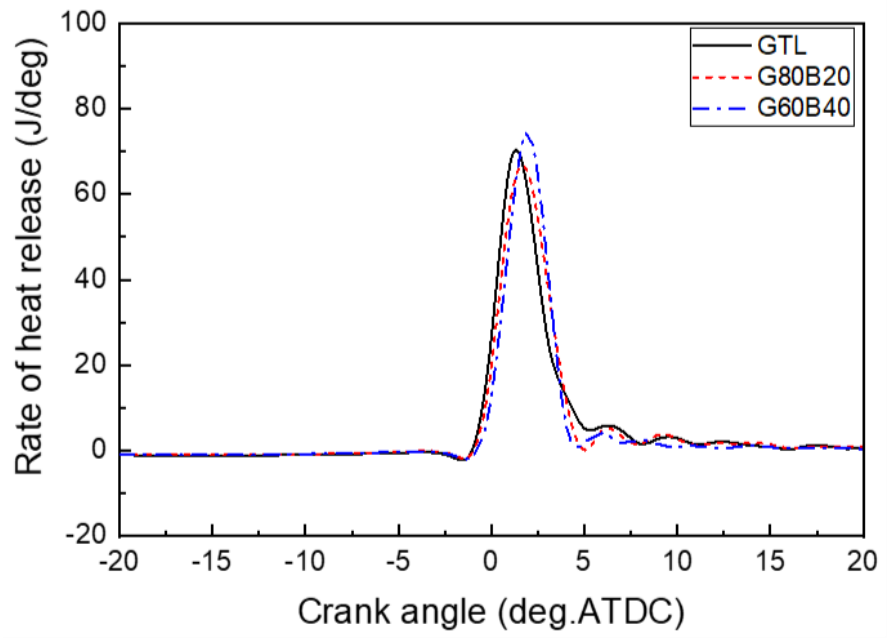

(b)

Figure 6. The effects of the GTL-biodiesel blends on the combustion pressure and rate of heat release $(\mathrm{ROHR})$ at $\mathrm{P}_{\text {inj }}=160 \mathrm{MPa}$ and $\theta_{\text {inj }}=\mathrm{BTDC}^{\circ}$. (a) Combustion pressure; (b) Rate of heat release.

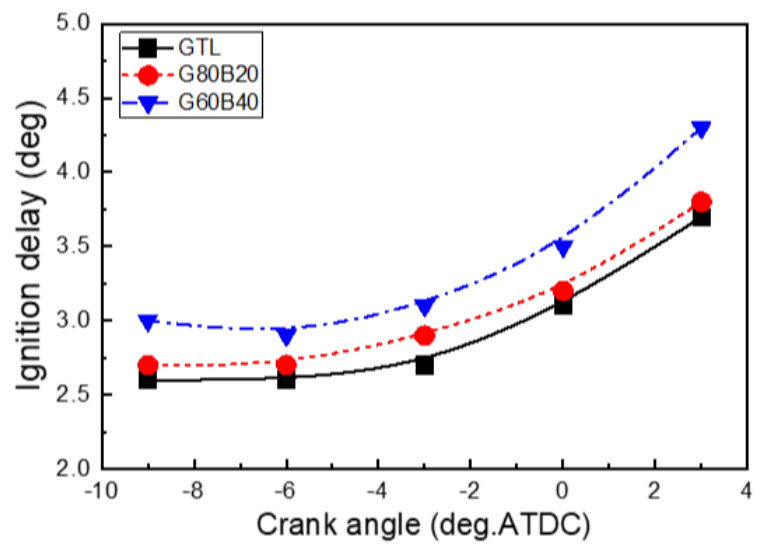

Figure 7. The ignition delays of the GTL-biodiesel blends at $P_{\text {inj }}=160 \mathrm{MPa}$ and $\theta_{\text {inj }}=$ BTDC $^{\circ}$. 
A comparison of the heat releases of the test fuels at various combustion phases is shown in Figure 8. As can be seen in the combustion energy distribution, the GTL fuel has the highest heat release, and the GTL-biodiesel blend shows a decreasing trend according to an increase in the biodiesel fuel. The amount of heat release for the G60B40 fuel indicated the lowest value, while the GTL fuel showed the highest value, because the heating value of the GTL is higher than that of the other fuels. In addition, the heat release of the premixed combustion duration for the GTL fuel is also the highest among the test fuels, and that of G60B40 is the lowest, as shown in Figure 8b.

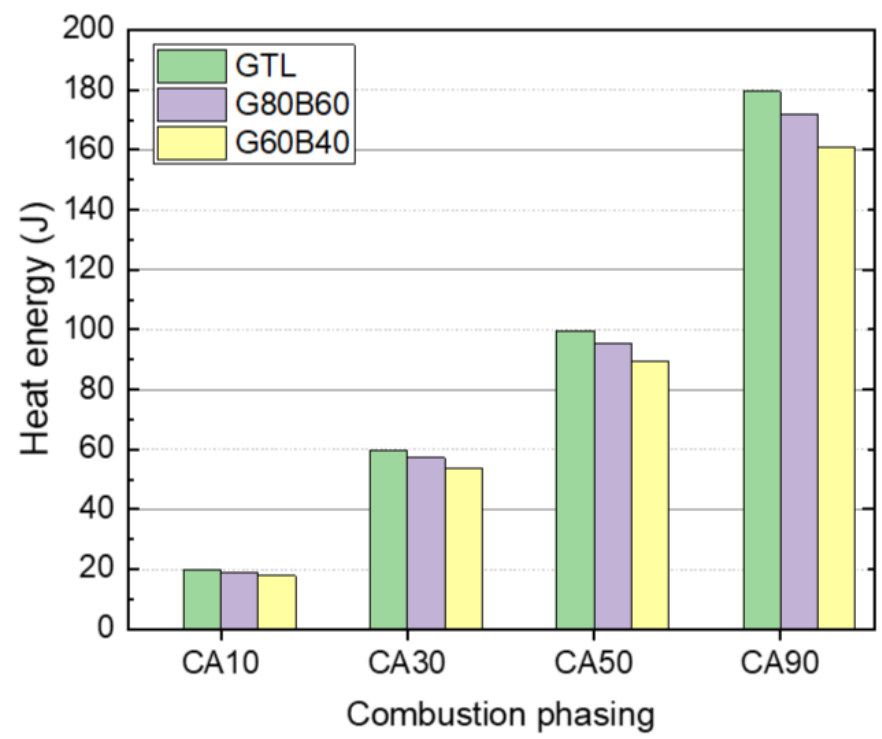

(a)

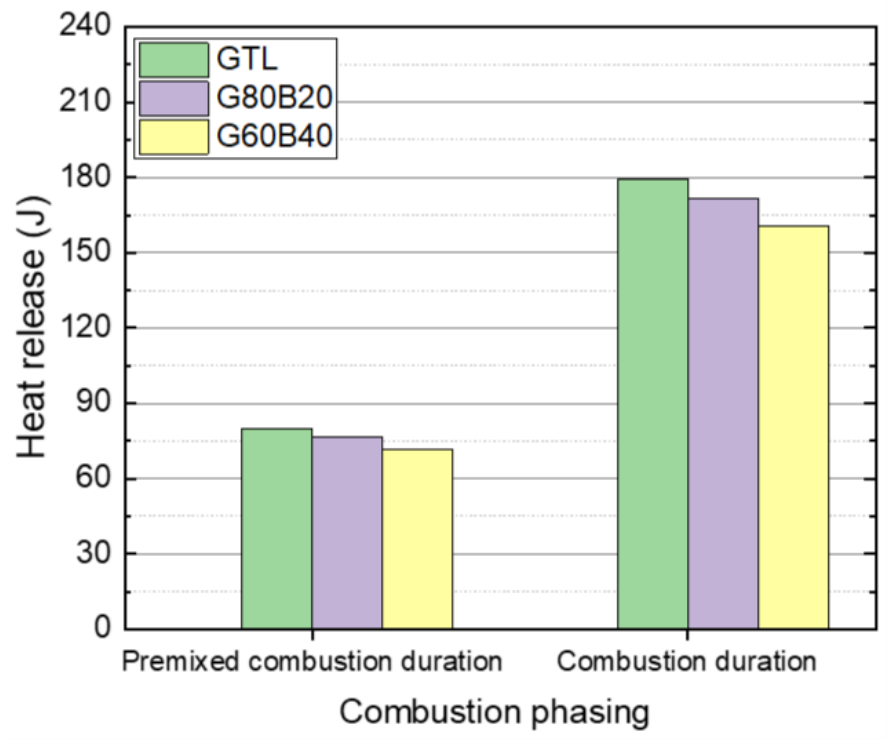

(b)

Figure 8. The heat release characteristics at $\mathrm{P}_{\text {inj }}=160 \mathrm{MPa}$ and $\theta_{\text {inj }}=\mathrm{BTDC}^{\circ}$. (a) Heat release; $(\mathbf{b})$ Heat release in the premixing combustion duration and combustion duration.

The exhaust emission characteristics of the GTL-biodiesel blended fuels is shown in Figures 9-11. The emissions are expressed in IS unit, which means that they are indicated specifically with the unit of $\mathrm{g} / \mathrm{kWh}$. The $\mathrm{NO}_{\mathrm{x}}$ emissions for the test fuels are presented as a function of the injection timing in Figure 9. In the figure, the GTL fuel exhibits lower $\mathrm{NO}_{x}$ emissions than the biodiesel blended GTL fuel across all of the injection timings. The results of several studies on the effects of the GTL fuel on diesel engines showed lower $\mathrm{NO}_{x}$ concentrations $[11,15,22]$. The formation of $\mathrm{NO}_{x}$ emissions is affected by 
various factors under different operating conditions, not one exact reason. Regarding the GTL fuel, the higher $\mathrm{CN}$ led to a shorter ignition delay, as shown in Figure 7. In terms of the fuel properties on the $\mathrm{NO}_{\mathrm{x}}$ formation, the significantly lower aromatic hydrocarbon content in the fuel reduces the adiabatic flame temperature, which enhances the reduction of the $\mathrm{NO}_{\mathrm{x}}$ formation. On the other hand, the effect of the test fuels on the $\mathrm{NO}_{x}$ emissions is smaller than that of the injection timings. As plotted in the $\mathrm{NO}_{\mathrm{x}}$ emissions, the advanced injection timing resulted in significantly increased $\mathrm{NO}_{\mathrm{x}}$ emissions because of the increasing amount of accumulated injections due to the advanced fuel injection.

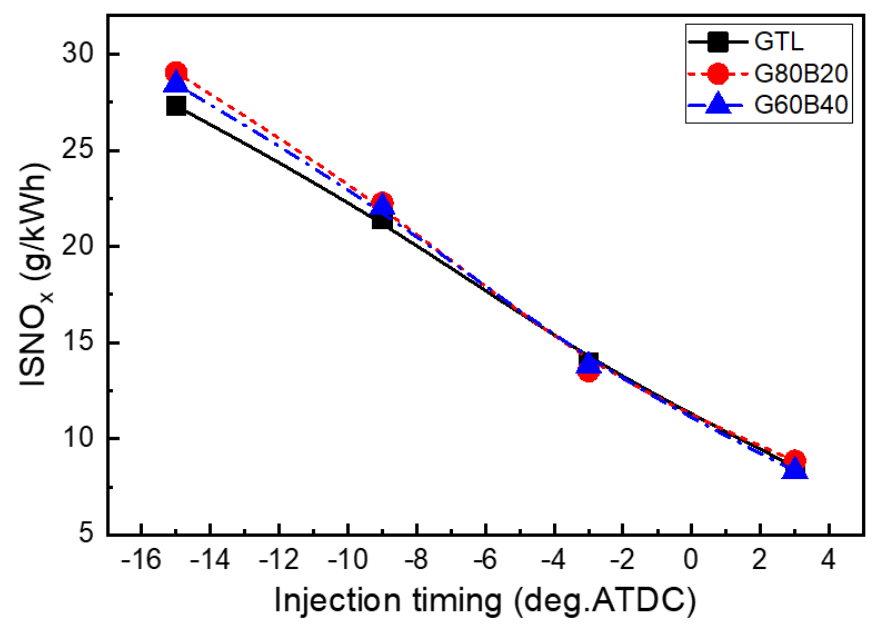

Figure 9. The effect of the GTL-biodiesel blend on the $\mathrm{ISNO}_{\mathrm{x}}$ emissions $\left(\mathrm{ISNO}_{\mathrm{x}}\right.$ : indicated specific nitrogen oxides).

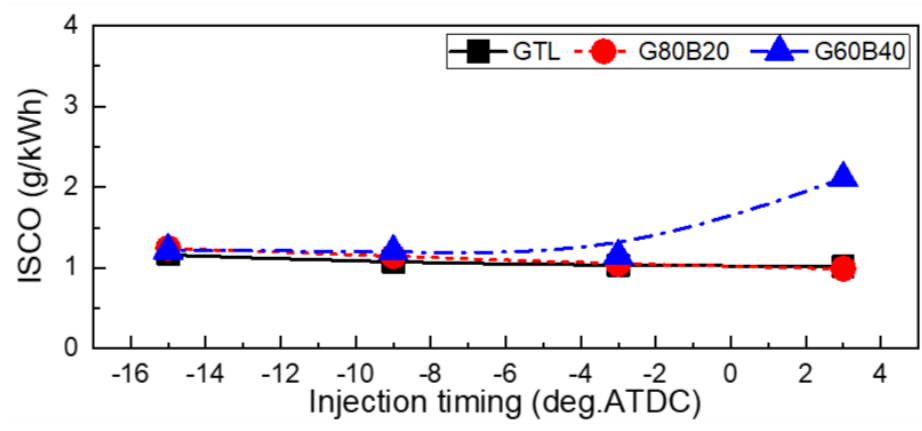

(a)

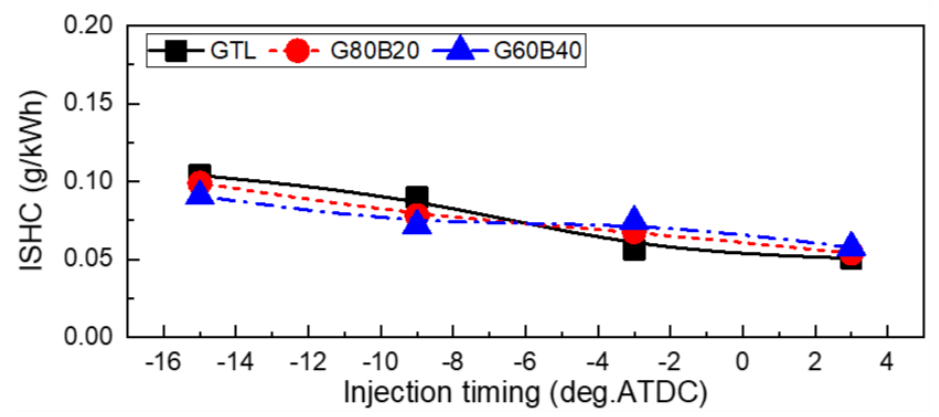

(b)

Figure 10. The effects of the GTL-biodiesel blend on the ISCO and ISHC emissions (ISCO: indicated specific carbon monoxide and ISHC: indicated specific hydrocarbon). (a) ISCO emission; (b) ISHC emission. 


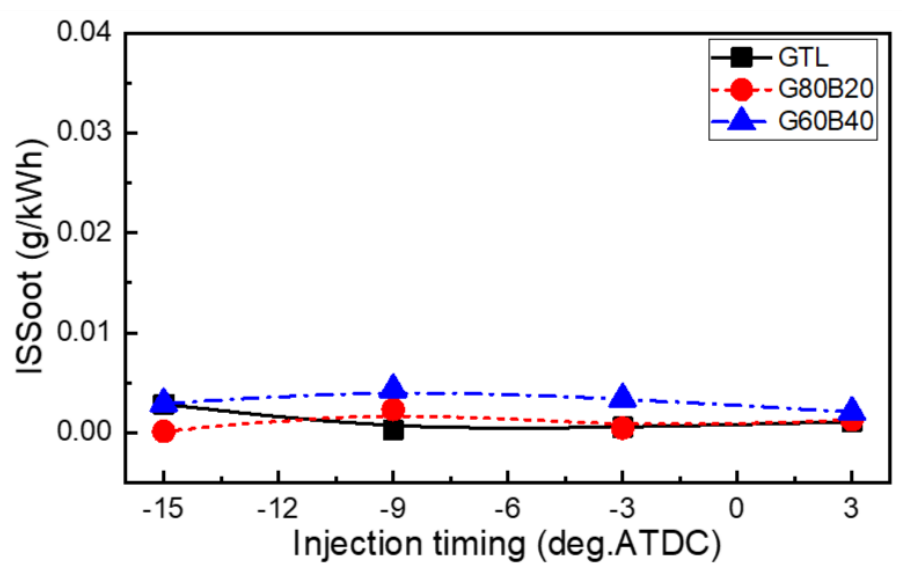

Figure 11. The effect of the GTL-biodiesel blend on the ISSoot emissions (ISSoot: indicated specific soot).

Figure 10 shows the effects of the GTL-biodiesel blends on the $\mathrm{CO}$ and $\mathrm{HC}$ emissions at an injection pressure of $160 \mathrm{MPa}$. In the range of the injection timing over $9^{\circ} \mathrm{BTDC}$, the $\mathrm{CO}$ emissions of the GTL fuel were almost similar to those for the GTL-biodiesel blends, while the higher blend of biodiesel showed more of an increasing trend than the lower blended fuels did (GTL and G80B20) at the retarded range. In the retarded injection timing, the higher blending ratio of the biodiesel is influenced by the late evaporation of the G60B40 fuel because of the poor evaporation and short mixing duration resulting from the reduction of the premixed combustion in the combustion chamber. The HC emissions showed a slight increase at the range of the advanced injection timings. Regarding the HC emission, the GTL and GTL-biodiesel blends showed lower HC emissions. As was the case with the $\mathrm{CO}$ emission, the reduction of the $\mathrm{HC}$ emissions can be attributed to the fuel properties and higher $\mathrm{CN}$. In particular, the higher CN of the GTL and GTL blends shortens the ignition delay, and the low distillation temperature enhances the fuel evaporation characteristics and the mixing with the air and fuel particles to improve the effective combustible charge in the engine. As mentioned above, the lower LHV and higher viscosity of the biodiesel brings about the deterioration of the GTL blend reaction and specific power performance due to an incomplete combustion. Therefore, the GTL fuel results in lower unburn hydrocarbon emissions in the exhaust emissions [11,15].

Figure 11 shows the soot emission distribution of the test fuels according to the injection timing. As illustrated in this figure, the effect of the GTL-biodiesel blends on the soot emissions are not significant. However, the GTL fuel showed a lower value than the other fuels. The GTL fuel properties, such as zero sulfur and the low aromatic content associated with a higher hydrogen-carbon ratio, may suppress the formation of particulate precursors [5]. In particular, the measured ISSoot emission indicated lower values compared to other emissions, and the formation of soot influenced by the excellent CN of the GTL fuel and the kinematic viscosity of the biodiesel in the GTL-biodiesel blends. Therefore, the higher fraction of the biodiesel fuel resulted in a slightly higher emission than that of the lower blending ratio of the biodiesel in GTL blends. The GTL fuel has a higher CN than the biodiesel fuel; therefore, the combustion improvement of the GTL may also favor a decreased smoke emission.

\section{Conclusions}

This study is an experimental study on the properties, combustion and exhaust emission characteristics of GTL-biodiesel blended fuels. The study of the combustion and emission characteristics was carried out using a single-cylinder diesel engine, and the effects of changes in properties (density, kinematic viscosity, cetane number, and lower heating value) were analyzed in terms of the various blending ratios of GTL and biodiesel. The following important conclusions were drawn from this study. 
1. The increasing rate of the density and kinematic viscosity of GTL-biodiesel blends at various temperature conditions was increased with increasing biodiesel volumetric fractions. Based on the investigation results of the GTL-biodiesel blending ratio, the increase in the GTL fraction in the GTL-biodiesel blends led to increases in the CN and LHV of blends.

2. The use of biodiesel-blended GTL fuels resulted in the extension of the ignition delay due to the increased biodiesel fraction in the GTL-biodiesel fuel. The increase in the GTL blending ratio led to a decrease in the delay period because of the higher vaporization property.

3. The GTL fuel exhibits lower $\mathrm{NO}_{\mathrm{x}}$ emissions than conventional diesel and biodiesel blended GTL fuel throughout the entire range of fuel injection timings. The $\mathrm{NO}_{\mathrm{x}}$ emissions increase with increasing biodiesel fractions in the blends.

4. The effects of GTL-biodiesel blends on the soot emission are small, but the GTL fuel showed a lower value than the other fuels. In the range between $15^{\circ} \mathrm{BTDC}$ and $3^{\circ} \mathrm{BTDC}$ of the injection timing, the $\mathrm{CO}$ emissions showed almost similarly low values for GTL-biodiesel blends, while the retarded range showed slightly lower and slightly increased HC emissions than those of the GTL fuel at advanced and retarded injection timings, respectively.

5. Unlike other studies that reveal combustion characteristics, the results of this study are thought to be of great benefit to alternative fuel research, such as GTL, biodiesel, and GTL-biodiesel blended fuels, for compression ignition diesel engines, by comprehensively studying the properties, as well as the combustion and exhaust emission characteristics of GTL-biodiesel blended fuels.

Author Contributions: All authors contributed to the experiments, analysis, and the deployment of the paper. developing study methodology, engine test, data analysis and fuel property measurement, K.C.; Experiments, result analysis, developing the research method and fuel property analysis, S.P.; Test engine design, engine experiments and data analysis, H.G.R.; Experimental design, data analysis, engine test, summarizing and correspondence of the paper, C.S.L.

Funding: This study was funded by the National Research Foundation of Korea (NRF) funded by the Ministry of Education of the Republic of Korea, grant number 2016R1D1A3B03935537 and 2015R1A4A1041746.

Conflicts of Interest: The authors declare no conflict of interest.

\section{Nomenclature}

\begin{tabular}{|c|c|}
\hline ATDC & after top dead center \\
\hline BTDC & before top dead center \\
\hline CAxx & crank angle at $x x^{\%} \%$ of the cumulative heat release \\
\hline $\mathrm{CN}$ & cetane number $(-)$ \\
\hline GTL & gas-to-liquid \\
\hline GxxByy & $\mathrm{xx} \%$ GTL + yy\% biodiesel blended fuel \\
\hline $\mathrm{ISNO}_{\mathrm{x}}$ & indicated specific nitrogen oxides (g/kWh) \\
\hline ISCO & indicated specific carbon monoxide $(\mathrm{g} / \mathrm{kWh})$ \\
\hline ISHC & indicated specific hydrocarbon $(\mathrm{g} / \mathrm{kWh})$ \\
\hline ISSoot & indicated specific soot $(\mathrm{g} / \mathrm{kWh})$ \\
\hline LHV & lower heating value $(\mathrm{MJ} / \mathrm{kg})$ \\
\hline$P_{\text {inj }}$ & injection pressure (Mpa) \\
\hline ROHR & rate of heat release $(\mathrm{J} / \mathrm{deg})$ \\
\hline $\mathrm{T}$ & temperature $\left({ }^{\circ} \mathrm{C}\right)$ \\
\hline T90 & $90 \%$ distillation point \\
\hline TDC & top dead center \\
\hline$\theta_{\text {inj }}$ & energizing duration (degree) \\
\hline$\rho_{\text {blend }}$ & the density of the blend $\left(\mathrm{kg} / \mathrm{m}^{3}\right)$ \\
\hline$r_{\text {Density }}$ & the rate of the density change $(\%)$ \\
\hline$\rho_{\mathrm{GTL}, 20^{\circ} \mathrm{C}}$ & the GTL density at $20 \mathrm{oC}$ and $1 \mathrm{~atm}\left(\mathrm{~kg} / \mathrm{m}^{3}\right)$ \\
\hline$v_{\text {blend }}$ & the blend viscosity $\left(\mathrm{mm}^{2} / \mathrm{s}\right)$ \\
\hline$r_{\text {viscosity }}$ & the rate of the kinematic viscosity change (\%) \\
\hline$\tau_{\text {id }}$ & ignition delay \\
\hline
\end{tabular}




\section{References}

1. Swain, P.K.; Das, L.M.; Naik, S.N. Biomass to liquid: A prospective challenge to research and development in 21st century. Renew. Sustain. Energy Rev. 2011, 15, 4917-4933. [CrossRef]

2. Bezergianni, S.; Dimitriadis, A. Comparison between different types of renewable diesel. Renew. Sustain. Energy Rev. 2013, 21, 110-116. [CrossRef]

3. Armas, O.; Yehliu, K.; Boehman, A.L. Effect of alternative fuels on exhaust emissions during diesel engine operation with matched combustion phasing. Fuel 2010, 89, 438-456. [CrossRef]

4. Oguma, M.; Goto, S.; Oyama, K.; Suguyama, K.; Mori, M. The possibility of gas to liquid (GTL) as a fuel of direct injection diesel engine. SAE Technol. Pap. 2002, 2002, 1706.

5. Sajjad, H.; Masjuki, H.H.; Varman, M.; Kalam, M.A.; Arbab, M.I.; Imtenan, S.; Ashraful, A.M. Influence of gas-to-liquid (GTL) fuel in the blends of Calophyllum inophyllum biodiesel and diesel: An analysis of combustion-performance-emission characteristics. Energy Convers. Manag. 2015, 97, 42-52. [CrossRef]

6. Sajjad, H.; Masjuki, H.H.; Varman, M.; Kalam, M.A.; Arbab, M.I.; Imtenan, S.; Ashrafur Rahman, S.M. Engine combustion, performance and emission characteristics of gas to liquid (GTL) fuels and its blends with diesel and bio-diesel. Renew. Sustain. Energy Rev. 2014, 30, 961-986. [CrossRef]

7. Armas, O.; Gómez, A.; Ramos, A. Comparative study of pollutant emissions from engine starting with animal fat biodiesel and GTL fuels. Fuel 2013, 113, 560-570. [CrossRef]

8. Abdul-Manan, A.F.N.; Bakor, R.Y.; Zubail, A.H. Analyzing the effects of Gas-to-Liquid (GTL) diesel blending on the efficiency and emissions of petroleum refineries and transport fuels in the U.S. and Europe. Transp. Res.-D 2018, 59, 259-267. [CrossRef]

9. Du, J.; Sun, W.; Wang, X.; Li, G.; Fan, L. Experimental study on combustion and particle size distribution of a common rail diesel engine fueled with GTL/diesel blends. Appl. Therm. Eng. 2014, 70, 430-440. [CrossRef]

10. Ezzitouni, S.; Soriano, J.A.; Gómez, A.; Armas, O. Impact of injection strategy and GTL fuels on combustion process and performance under diesel engine start. Atmos. Environ. 2018, 177, 214-221. [CrossRef]

11. Wang, H.; Hao, H.; Li, X.; Zhang, K.; Ouyang, M. Performance of Euro III common rail heavy duty diesel engine fueled with Gas to Liquid. Appl. Energy 2009, 86, 2257-2261. [CrossRef]

12. Lapuerta, M.; Armas, O.; Hernadez, J.J.; Tsolake, A. Potential for reducing emissions in a diesel engine by fueling with conventional biodiesel and Fischer-Tropsch diesel. Fuel 2010, 89, 3106-3113. [CrossRef]

13. Soltic, P.; Edenhauser, D.; Thurnheer, T.; Schreiber, D.; Sankowski, A. Experimental investigation of mineral diesel fuel, GTL fuel, RME and neat soybean and rapeseed oil combustion in a heavy duty on-road engine with exhaust gas after-treatment. Fuel 2009, 88, 1-8. [CrossRef]

14. Hassaneen, A.; Munack, A.; Ruschel, Y.; Schroeder, O.; Krahl, J. Fuel economy and emission characteristics of Gas-to-Liquid (GTL) and Rapeseed Methyl Ester (RME) as alternative fuels for diesel engines. Fuel 2012, 97 , 125-130. [CrossRef]

15. Li, X.; Huang, C. Emission reduction potential of using gas-to liquid and dimethyl ether fuels on a turbocharged diesel engine. Sci. Total Environ. 2009, 407, 2234-2244.

16. Huang, Y.; Zhou, L.; Wang, S.; Liu, S. Study on the performance and emissions of a compression ignition engine fuelled with Fischer-Tropsch diesel fuel. J. Automob. Eng. 2006, 220, 827-835.

17. Abián, M.; Martín, C.; Nogueras, P.; Sánchez-Valdepeñas, J.; Alzueta, M.U. Interaction of diesel engine soot with $\mathrm{NO}_{2}$ and $\mathrm{O}_{2}$ at diesel exhaust conditions. Effect of fuel and engine operation mode. Fuel 2018, 212, 455-461. [CrossRef]

18. Park, S.H.; Lee, D.; Lee, C.S. Influence of gas-to-liquid fuel on the combustion and pollutant emission characteristics. J. Automob. Eng. 2014, 228, 85-93. [CrossRef]

19. Abu-Jrai, A.; Tsolakis, A.; Theinnoi, K.; Cracknell, R.; Megaritis, A.; Wyszynski, M.L.; Golunski, S.E. Effect of Gas-to-Liquid Diesel Fuels on Combustion Characteristics, Engine Emissions, and Exhaust Gas Fuel Reforming Comparative Study. Energy Fuel 2006, 20, 2377-2384. [CrossRef] 
20. Li, X.; Huang, Z.; Wang, J.; Zhang, W. Particle size distribution from a GTL engine. Sci. Total Environ. 2007, 382, 295-303. [CrossRef] [PubMed]

21. Park, S.H.; Choi, K.; Kim, M.Y.; Lee, C.S. Experimental investigation and prediction of density and viscosity of GTL, GTL-biodiesel, and GTL-diesel blends as a function of temperature. Eenergy Fuel 2013, 27, 56-65. [CrossRef]

22. Yehliu, K.; Boehman Andre, L.; Armas, O. Emission from different alternative fuels operating with single and split fuel injection. Fuel 2010, 89, 423-437. [CrossRef]

(C) 2019 by the authors. Licensee MDPI, Basel, Switzerland. This article is an open access article distributed under the terms and conditions of the Creative Commons Attribution (CC BY) license (http://creativecommons.org/licenses/by/4.0/). 